\title{
The Formulation of Student Social Interaction Model at Halal Tourism Area on Lombok Island
}

\author{
Waslul Abral \\ College Student of Magister Program of Geography Education \\ Faculty of Social Science, Universitas Negeri Padang, Indonesia \\ Email: waslulabral04@gmail.com
}

\begin{abstract}
This study aims to formulate a model of student social interaction, especially junior high school students at the halal tourism area on the Lombok island.The method used is mixed method with data collection conducted by purposive sampling technique and Analitycal Hierarchy Process (AHP). The result and discussion of alternative policy of social interaction development in Lombok island, West Nusa Tenggara Province, Indonesia are: (1) Increasing parent role of student. (2) Strengthening the role of ulama / community leaders. (3) Teachers instil positive social interaction of students through school and laity programs. (4) The government has an important role in facilitating the parents, teachers and ulama / community leaders in developing positive social interaction of students, so that social conflicts that can cause dispute in Lombok society can be avoided.
\end{abstract}

Keywords: Model, Interaction, Tourism, Halal

\section{Intruduction}

West Nusa Tenggara Province is one of the provinces in Indonesia. West Nusa Tenggara Province consists of two large islands, namely Lombok island and Sumbawa island. Mataram city on the island of Lombok is the provincial capital of West Nusa Tenggara and largest city in the province. Lombok Island as the second tourist destination after Bali which has many uniqueness, especially in tourism (Gunawan and Purnama, 2015; Chanin et al., 2015; Chookaew et al., 2015; Gabdrakhmanov et al., 2016) Tourism on the island of Lombok has been growing since the 1990s with the increase of tourism on the island of Bali since 1986 (Dahles and Bras, 1999 in Kurniawan et al., 2016). Lombok Island is an island of Indonesia predominantly Muslims and known as Mosques Thousand of island (Sulhaini et al.,2017).

In 2012 the Government of Indonesia intends to promote the Halal Tourism in Indonesia.The government promoted the 12 destinations which are Moslem friendly destination. The 12 destinations are Aceh, West Sumatra, Riau, Lampung, Banten, Jakarta, West Java, East Java, Central Java, Yogyakarta, West Nusa Tenggara and South Sulawesi (Nirwandar, 2015 in Firdausi et al., 2017). The Indonesian government gave attention to Lombok tourism potential and wants to develop it toward the Halal Tourism to attract more foreign tourists, especially Muslim populated countries. This effort is supported by the Indonesian government with the acceleration of development in Lombok island.

West Nusa Tenggara is awarded as World's Best Halal Tourism Destination and two more awards in 2016 (World's Best Halal Honeymoon Destination and the 1st World's Best Halal Tourism Destination) from World Halal Tourism Award (Firdausi, 2017). The island of Lombok has become one of the most popular destinations for tourists to continue their journey from the island of Bali to the island of Lombok because the island of Lombok has the beautiful places such as Senggigi beach, Kuta Mandalika beach, Pink beach, Sendanggile waterfall and Rinjani mountain. Lombok also has enormous potential as a Halal Tourism 
Destination. Tourists do not only enjoy the beautiful natural environment but also they can visit the religious tourism sites of Islam which is first developed (Nashuddin, 2016).

The Sasak tribe is the largest ethnic group on the island of Lombok. The population of Sasak community is about 2.6 million at the beginning of the 21 st century (Rahayu, 2016). The Sasak tribe is the community that adheres to the teachings of Islam and has deeply tradition, harmonious and keep their environment. The traditions of customs and religious life run simultaneously for many years. Indigenous and religious figures have a prominent position in the social life of the Lombok community. Lombok inhabitants (mainly Sasak tribes) use Sasak language, in some places use the language of Bali as their daily conversation language (Achmad Rosidi, 2011). The social interaction of the Lombok community is related to a sense of togetherness that is manifested in communication about the attitude and moral agreement, religious, ethnic and indigenous communities for the creation of a harmonious environment. The development of local wisdom-based tourism model that suits with socio-cultural and economic of Lombok community is the Halal Tourism Destination. The successful of the Halal Tourism should involve informal and non-formal leaders such as Tuan Guru, custom leaders, ulama, community leaders and educators at schools. Schools make programs that can provide information and early teaching to learners to encourage them to interact positively in the area of the Halal Tourism Destination.

The Halal Tourism is a kind of religious tourism that applies Islamic teachings to be popular all over the world, especially among Muslim consumers (Mohsin, Ramli, \& Alkhulayfi, 2015 in Putra et al., 2016). The Halal Tourism can be considered as a merger of tourism consumer habits and Islamic lifestyle. Each tourist object or action that is allowed according to Islamic teachings to be used or involved by Muslims in the tourism industry (Battour \& Ismail, 2016 in Elaziz, 2017). The Halal Tourism is a new product in the tourism industry. This is a subcategory of religious tourism which is inclined to Muslim families who adhere to sharia rules. The word "halal" means permitted - created or operated in accordance with Islamic law. The concept of halal in Arabic means permission, it is not just food but also it includes everything which is sharia compliant, and halal tourism means offering tour packages and destinations that are purposely designed to support Muslim tourists. Many Muslim travelers are looking for the "halal" label on hotels, restaurants and even airlines when they travel. According to halal tourism the hotels in such destinations do not serve alcohol and pork, prayer timings are announced, the hotel rooms should have a Qibla pointing signage stuck on the ceiling or in drawers, and a prayer mat to allow the Muslim travelers to perform their religious obligations. It also includes other facilities separate for men and women such as in hotels and resorts etc.(Mansouri, 2014; Bozorgaghideh, 2015; Battour, 2015; Kessler, 2015; Ni'mah and Sari, 2016; Puangniyom, 2017 ).

Shariah concept is not to discourage people of other religion to experience the service of the hotel, but to rather support and accommodate Muslims with the needed facilities and not jeopardize the qualities of a conventional hotel to guests that may not believe in the same faith (Saifuddin et al ., 2015). The Halal Tourism has a positive impact on the economy of Lombok community. But the government should be able to control the investment in the area so that people are not harmed. The religious and tribal clarity in Lombok should also be a concern. Political interests and partisanship towards a particular community will lead to jealousy and social conflict that will threaten the integrity and unity of the region.

Tourism developers, generally is grouped into three main pillars, namely: (1) community, (2) private sector, and (3) the government. The community which is meant is the general public at the destination as the legitimate owner of various resources and a tourism resource, community leaders, intellectuals, social institutions and the media. Furthermore, the private group is an association of tourism companies and entrepreneurs, while the governments are in various areas of government, ranging from central government, provinces, districts, and so forth (Pitana \& Gayatri, 2005 in Sham, 2017). 
Destination attributes affect tourists satisfaction and decision making processes. If tourists have a positive perception of the attribute of objective, they will willingly come back (Bonn, Joseph \& Dai, 2005 in Rahman, 2014). The successful of the objective attribute depends on the level of goal satisfaction and goal loyalty. The tourist destination attributes consist of climates, historical objects, sunsets, scenic beauty, beaches, snow, cultural events, recreational opportunities, experiences, rest and relaxation, self-esteem, prestige, health and fitness, adventure, social interaction, benefits, interests, and pictures accessibility marketed (Battour et al., 2011 in Rahman, 2014). The attributes of Islam in Malaysia have a significant relationship with Islamic travel and destination loyalty at $\mathrm{p}<0.01$. Therefore, H1a and H1b are acceptable. The destination attribute has a positive impact on foreign tourists (Rahman, 2014). Tourists from different cultures will have different cultural values and social behavioral rules, perceptions, and social interactions, which in turn will affect their lifestyles, work patterns, relaxed ways and consumption patterns. Based on the results of the test analysis of the differences that have been concluded that there are differences in the behavior of activities, interactions, and transactions between Australian and Indonesian tourists in tourism activities on the island of Lombok (Rinuastuti, 2015).

According to Khalik (2013), there are currently three great powers that compete each other, namely tradition, Islam and the modern world. All three are the source of the values and norms of the Sasak community today. These three powers combine to form new belief systems, values and norms. But it must be admitted that the quality and level of the new system differ significantly from city to village and to areas where the presence of teachers dominates other influences.

One of the functions of the teachers existence is to encourage students to have a positive social interaction so this influences the positive image of Lombok island tourism. However, when tourism is expected to increase Lombok's economic revenues, emerging issues of socio-cultural and environmental conflict as an impact of the tourism industry. From social interaction side will occur the changes in patterns of social interaction of students who are not in accordance with the values applicable to the Lombok society, for example, the minors (children) will tend to prefer money than school, the treatment of parents who are strict on religious values as well as customs will begin to loose in everyday behavior and association.

Social interaction is a relationship experienced by every individual, including students. With good social interaction, students are expected to develop their potential. The potential that develops maximum produces satisfactory learning outcomes. The results of good learning is followed by good social interaction skills as well (Fernanda, 2012). Student self potential can develop in the form of positive self-concept so that generates a positive influenceon student learning outcomes and social skills. Talented students have excellent abilities in achievement, self-confidence, personality, self-concept, social skills and moral values. Through interaction people can build communities, commit to each other and create close social relationships. Well social network has the potential to bring great benefits to society (Field, 2003 in Afifi and Latifah, 2017).

According to Saharuddin in Afifi \% Latifah, 2017) there are at least three types of social capital in the Sasak community which construct social cohesiveness values. Social capital here refers to the forms of interaction (brotherhood and collaboration), institutions, and norms. As a peasant traditional community, Sasak has several languages terms relating to the activities of cooperation or solidarity inmanaging rice fields, which may be classified as social capital. Some of these are najen, nginjam, bêsiru, bêkelompok, bêdêrêp, and bêgae. The most common term used by Sasak community is besiru, which literally means "mutual help." Besiru is an expression of solidarity and cohesiveness of the community in helping, as well as supporting each other without expecting any wage. It appears in social events such as farm cultivation, wedding parties, building houses, death and funeral ceremonies. Related to social capital, social interaction includes togetherness, competition and conflict (Melchioriyusni, 2013). Social interaction can be an exchange of thoughts to work collaboratively on a task or form a bond of friendship outside the classroom. 
The reach and quality of these interactions may all have an impact on outcomes. In the learning activities leaners are assigned to work together and leaners form social relationships within the classroom (Alhassan, 2015).

Schools as part of social interaction activities are expected to be able to develop Shariah or kosher values according to Islamic principles in accordance with the characteristics of Lombok community in the interaction activities in schools and the community. Characteristics of students in accordance with the values of sharia in the tourist area on the island of Lombok such as aspects of cooperation, mutual cooperation, hospitality, friendly, honest, trust, like to help and say the word greetings, forgiving and gratitude and not lead to individualism, promiscuity or western style.

\section{Method}

The type of this research is quantitative descriptive research. Descriptive research is the assessment conducted to determine the value of independent variables without making a comparison or build relationships with other variables. Quantitative research is the researcher conducted tests of hypotheses with statistical techniques. The statistic data were obtained from questionnaires using Analytical Hierarchy Process (AHP) method (Saaty, 2008, Syam, 2017; Oktorie, 2017). The method used was mixed method (Syam, 2017;), with data collection done by technique Purposive Sampling and Analityal Hierarchy Process (AHP) through observation, interview, questionnaire and literature review. The subjects of the study were students on the Halal Tourism Destination on the island of Lombok. The use of Analitycal Hierarchy Process (AHP) is to choose alternatives or to prioritize the development of students social interaction on the island of Lombok.

\section{Results and Discussion}

The students' social interaction at the Halal Tourism Destination on the island of Lombok is strongly influenced by the characteristics of the Sasak community, who are mostly Muslims, relatively religious, are marked by their solidarity in religious activities, both individually and collectively. Religious individually reflected in the enthusiasm in carrying out religious orders such as prayers five times a day a night and perform the pilgrimage to the holy land. Its social interaction activities are seen in the solidarity of death, marriage, the celebrations of Islamic religious holidays, the establishment of mosques, the construction of madrasa and so on. When the interaction happened with the outside world intensively so as a very rapid socio-cultural change will also happen, because the potential of the Halal Tourism of Lombok island is internationally recognized. Based on the observations and the interviews of the students' social interactions on the island of Lombok, West Nusa Tenggara which is formed in the local- wisdom and tradition of Sasak community who are religious, socially concerned, helpful, tolerant and respectful, created a harmonious atmosphere. The social interaction that occurred in Lombok island began to change the order or the values of society when foreign tourists came. According to Surwiyanta (2003), with the tourism activities, the leniency of parental treatment of their children, from strict rule or discipline to being free to choose what they aspire, there is a positive change in communicating with others so as to eliminate negative prejudices to other ethnics. However, if it is not observed, tourism will damage the order of living values of society.

Furthermore, Nararya \% Pranggono (2016), the tourism activities on the island of Lombok constrained its development on socialization, and public education. The existence of entertainment places contrary to the concept of Islamic tourism. According to the government this invites many problems, one of which is noise and immoral activities. The threat of comfort and security of tourists can also be influenced and caused by 
various factors, such as terrorist acts, local conflicts, natural disasters, social behavior, social wars (conflict), and public extortion of other members of the community so that those factors can cause to a decrease in security for tourists (Khalik, 2014).

The social problems are the weakness impact of the management system in managing of tourism. The agreement between the government and the people in the tourism area should be strived to avoid social conflicts in community (Nashuddin, 2015). According to Rosidi (2011), the arrival of tourists to Lombok island with different socio-cultural backgrounds from the Sasak community can cause problems for the religious harmony in this region. The issue of religion becomes a sensitive issue that causes the community to be easily provoked and burned emotionally like the incident in 2001 . The contribution of religious leaders and community leaders greatly helped the performance of local governments in creating a conducive life.

Based on the above description, the students' social interaction in Lombok's Halal Tourism area will be influenced by socio-cultural problems that occur in Lombok society, which can slowly damage the religious values and noble culture of Sasak people. Social conflicts must be prevented early in order for students to have a broad insight in the face of problems that will lead to divisions within Lombok community. Individualism began to emerge as economic needs, solidarity and mutual help began to wane if students were not directed to the characteristics of the Lombok community in fact.

Based on the data obtained in this study in the Halal Tourism area of Lombok island, the social interaction of students can be grouped in three forms which described in three assessment criteria. According to Gillin and Gillin, social interaction includes the relationship between one individual with another individual, between groups of people and individuals with groups (Fernando, 2012). After an interview with the expert, 3 types of social interaction between the individual and individual interaction with group and group interaction with the group were identified. The decision making alternative for the development of the three types of social interaction was strongly influenced by the role of teachers, parents, / community leaders and government.

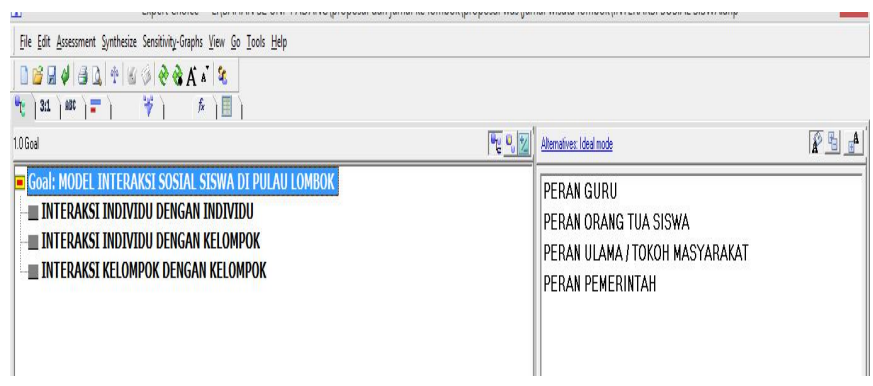

Figure 1. Goal and Alternative Forming Hierarchy Structure The Student Social Interaction on the island of Lombok

Information :

a. Goal Level b Level Criteria c. Alternative
: The goal of the decision is expected student social interaction

: Criteria for the type of student's social interaction.

: People that play a role in the development of students' social interactions

The interest rate scoring score is used in the Questionnaire and Expert Choiced applications in comparing the inter-criteria and among the assessed alternatives. Assessment is intended to compare values or character choices based on each criterion. For example between option 1 and option 2, on criterion 1, more important choice 1, then between option 1 and option 3, more important choice 3 and so on until all options are compared one by one (in pairs). The result of the assessment is the value / weight which is the character 
of each alternative. From the 3 criteria will be compared between one criterion with another criterion based on the importance level as in the table of importance level assessment below.

Table 1. Rating Score of Interest Score

\begin{tabular}{|c|l|}
\hline Score Value & \multicolumn{1}{|c|}{ Description } \\
\hline 1 & The one criterion with each other is just as important \\
\hline 2 & $\begin{array}{l}\text { The one criterion is slightly more important (somewhat stronger) than the other } \\
\text { criteria }\end{array}$ \\
\hline 3 & $\begin{array}{l}\text { Criteria that one character is more important (stronger importance) than other } \\
\text { criteria }\end{array}$ \\
\hline 4 & $\begin{array}{l}\text { One criterion is very important compared to other criteria } \\
\text { One criterion of extremes of importance over other criteria 2, 4, 6, } 8 \text { The } \\
5\end{array}$ \\
\hline
\end{tabular}

In AHP data processing, the easier way to do this weighting is to use the help of computer program (Expert Choice). So the role of each stakeholder in developing students' social interactions can be described as follows:

\section{Individual social interactions with individuals}

The role of parents is higher, while the role of teachers and clerics / community leaders is equally important, and the role of government is lower.

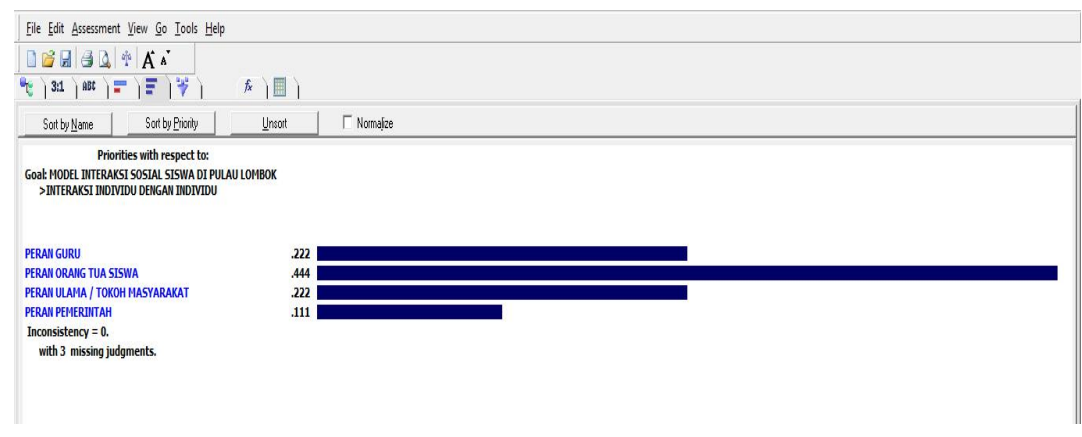

Figure 2. Alternative to individual social interactions with individuals

\section{The social interaction of individuals with groups}

The role of parents, ulama / community leaders and government is equally important, while the role of teachers is lower.

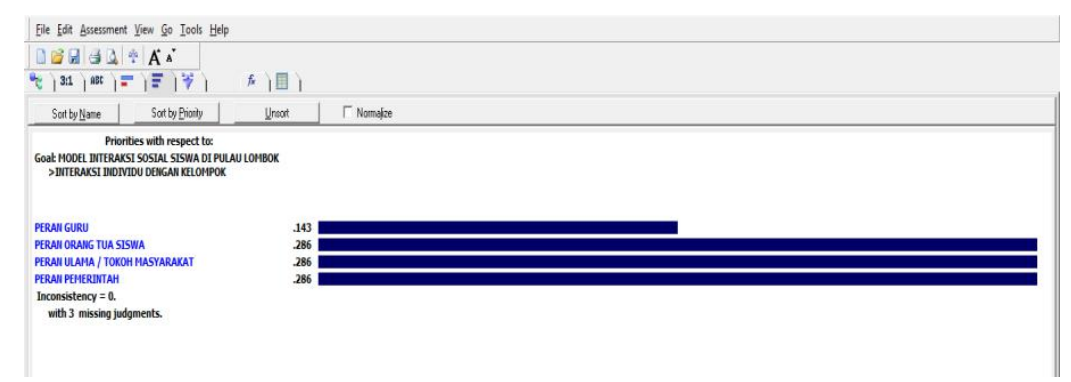

Figure 3. Alternative to the social interactions of individuals with groups 


\section{The social interaction of individuals with groups}

The role of parents, ulama / community leaders and government is equally important, while the role of teachers is lower.

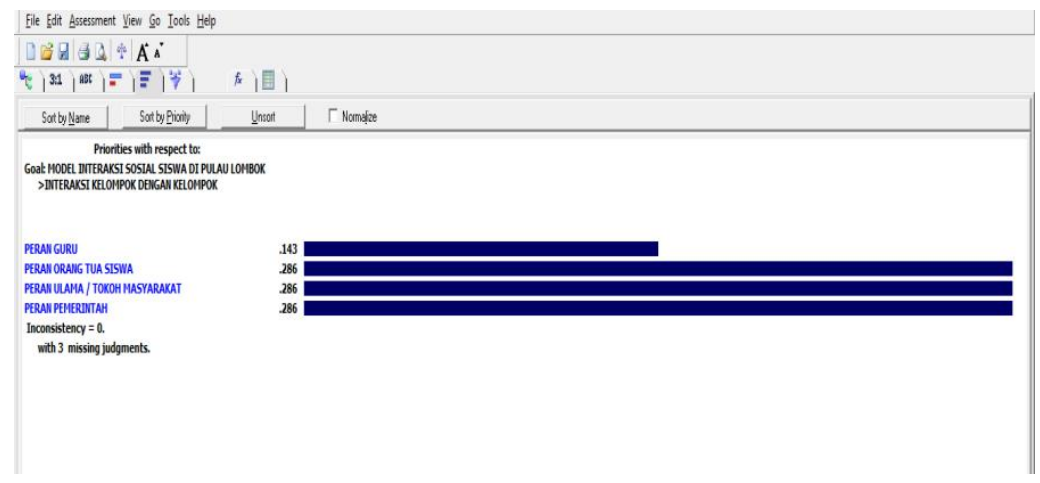

Figure 4. Alternative to the social interactions of individuals with groups

Based on the Analytical Hierarchy Process (AHP) analysis of the students' social interaction in the Halal tourism Destination of Lombok Island, the role of parents is more important in the development of positive social interaction, the role of teachers and ulama / community leaders also have a very important role, because teachers are role models in daily social interaction. The ulama and community leaders have a very important role, because the community of Lombok are very strong in maintaining their religious and noble cultural characteristics. The Master Teachers ( Tuan Guru) plays an important role in shaping the religious character of society. The great name of a Master Teacher becomes a symbol highly respected by the people. In accommodating the role of teachers, parents and ulama / community leaders should be facilitated and encouraged by the government in order to harmonious students' social interaction can be realized. According to Hafizah Awalia (2017), the government should be more neutral and fair to plurality to avoid internal and external conflicts of tribes and religions in NTB.

\section{Conclusion}

Based on the results of the discussion above, it can be concluded that the results of data processing the alternative hierarchy in the development of the social interaction of students in the Halal Tourism Area of Lombok island based on AHP analysis are: 1) improving the role of parents. 2) Strengthening the role of ulama / community leaders. 3) Teachers instil positive social interaction on students through school and laity programs. 4) The government has an important role in facilitating the parents, teachers and ulama/community leaders in developing positive social interaction of students so that the social conflicts that can cause dispute in Lombok community can be avoided.

\section{References}

Afifi, Mansur and Latifah, Sitti. (2017). Social Capital Revitalization of the Sasaq Community in Lombok, Indonesia through Learning Organization.Suvannabhumi Vol. 9 No. 1 (June 2017) 173-192.

Alhassan, Awal, M (2015).Students Social Interactions and Learning in a Multicultural School. International Journal of Research in Humanities and Social Studies V2 . I11 . November 2015

Battour, Mohamed and Ismail, Mohd. Nazari. (2015). Halal tourism: Concepts, practises, challenges and future. journal homepage: www.elsevier.com/locate/tmp. (C) 2015 Elsevier Ltd. All rights reserved 
Bozorgaghideh, Nargeskhatoon and S. Resia Beegam. (2015).Halal Tourism in Kerala.International Journal of Management (IJM) Volume 6, Issue 8, Aug 2015, pp. 42-48, ISSN Print: 0976-6502 and ISSN Online: 0976-6510 C IAEME Publication

Elaziz, Muhammet, F. and Kurt, Abdurrahman. (2017). Religiosity, consumerism and halal tourism: A study of seaside tourism organizations in Turkey. Original scientifi c paper. Vol. 65/ No. 1/ 2017/ $115-$ 128 UDC: $338.48-6.2(569)$

Fernanda, Mistio Mesa., Afrizal Sano \&Nurfarhanah. (2015). Hubungan Antara kemampuan Berinteraksi Sosial Dengan Hasil Belajar.Jurnal Ilmiah Konseling. http://ejournal.unp.ac.id/index.php/konselor. Volume 1 Nomor 1 Januari 2012

Firdausi, Izza., Marantika, Stanijuanita., Firdaus, Zein Nidaulhaq and Sajidah, Rifqah (2017). Lombok: Halal Tourism as a New Indonesia Tourism Strategy. 4th International Conference on Humanities, Social Sciences and Education (ICHSSE-17) March 13-14, 2017 Dubai (UAE)

Gabdrakhmanov, N. K., Biktimirov, N. M., Rozhko M. V. and Khafizova,L. V. (2016). Problem of Development of Halal Tourism in Russia. Journal of Organizational Culture, Communications and Conflict Volume 20, Special Issue2, 2016

Kessler, Kristel. (2015). Conceptualizing Mosque Tourism: A central feature of Islamic and Religious Tourism.International Journal of Religious Tourism and Pilgrimage.Volume 3 Issue 2 Selection of Papers from International Conference 2015 (V1)

Kurniawan, Fery., Adrianto, Luky., Bengen, Dietriech, G. and Prasetyo, Lilik Budi. (2016). Vulnerability assessment of small islands to tourism: The case of the Marine Tourism Park of the Gili Matra Islands,Indonesia. journal homepage: www.elsevier.com/locate/gecco. Global Ecology and Conservation 6 (2016) 308-326

Oktorie, Olivia. (2017). A Study of Landslide Areas Mitigation and Adaptation in Palupuah Subdistrict, Agam Regency, West Sumatra Province, Indonesia. Sumatra Journal of Disaster, Geography and Geography EducationISSN: 2580-4030 (Print) 2580-1775 (Online) Vol 1, No. 1, (pp. 43-49), June, 2017 http://sjdgge.ppj.unp.ac.id

Putra, Errid Hadisyah., Hati, Sri, R.H. and Daryanti, Sri. (2016). Understanding Muslim Customer Satisfaction with Halal Destinations: The Effects of Traditional and Islamic Values: 3rd International Conference on Business and Economics, 21-23 September, 2016. eISSN: 2357-1330

Rinuastuti, Baiq Handayani. (2015). Qonsequences of Cultural and Behavioral Difference of Tourist: Study of Australian and Indonesian Tourist Who Visit Lombok Island, West Nusa Tenggara.Journal of Indonesian Tourism and Development Studies. E-ISSN : 2338-1647. J.Ind. Tour. Dev. Std., Vol.3, No.2, April, 2015

Rosidi, Achmad . (2011). Pola Relasi Sosial Keagamaan Umat Beragama di Lombok Nusa Tenggara Barat. Peneliti Puslitbang Kehidupan Keagamaan. Jurnal Multikultural \& Multireligius Vol. X No. 3. Juli September 2011

Saaty, T. L., (2008). Decision Making with the Analytic Hierarchy Process. Int. J. Services Sciences, No. 1, Vol. 1, Hal $83-98$.

Surwiyanta, Ardi. (2003). Dampak Pengembangan Pariwisata Terhadap kehidupan Sosial budaya Dan Ekonomi. Media Wisata Vol.2 no 1 November 2013

Syam, Alexander. (2017). Development Strategy in Bio-Geophysic Ecological Area of Mandeh Tourism to Meet Asean Economic Community (MEA).Sumatra Journal of Disaster, Geography and Geography Education ISSN: 2580-4030 (Print) 2580-1775 (Online) Vol 1, No. 1, (pp. 50-56), June, 2017 http://sjdgge.ppj.unp.ac.id

Shirzad Mansouri. (2014). Role of Halal Tourism Ideology in Destination Competetiveness : AStudy of Selected Hotel in Bangkok, Thailand. International Conference on Law, Education and Humanities (ICLEH'14) Jan. 30-31, 2014 Pattaya (Thailand)

Sulhaini, Saufi A., Rusdan. (2017). Developing Halal Tourism Destination: Investigating Lombok's Potentials from Dstination marketing Perspective. In Saufi A., Andilolo I.,Othan N., Lew A. (eds) Balancing Development and Sustainability intourism destinations. Springer, Singapore 